\title{
KEEFEKTIFAN MODEL TEAM ASSISTED INDIVIDUALIZATION (TAI) TERHADAP HASIL BELAJAR SUBTEMA PELESTARIAN KEKAYAAN SUMBER DAYA ALAM
}

\author{
Dyah Dwi Sulistyoningsih ${ }^{1}$, Ernawati Saptaningrum ${ }^{2}$, Mei Fita Asri Untari ${ }^{3}$ \\ 1,2,3 PGSD FIP Universitas PGRI Semarang, \\ Jalan Sidodadi Timur No 24 Semarang \\ email : dyahdwi43@gmail.com
}

\begin{abstract}
Abstrak
Penelitian ini dilatar belakangi oleh kurangnya minat belajar siswa yang berakibat tidak tercapainya nilai KKM. Hal ini dikarenakan pembelajaran masih berpusat pada guru serta kurangnya kreativitas guru dalam memilih model pembelajaran dan media pembelajaran yang inovatif. Penelitian ini memiliki tujuan untuk mengetahui apakah model Team Assisted Individualization (TAI) efektif terhadap hasil belajar Subtema Pelestarian Kekayaan Sumber Daya Alam di Indonesia kelas IV SD N Sidomulyo 04 Ungaran. Jenis penelitian ini adalah penelitian kuantitatif dalam bentuk Pre Experimental Design dengan jenis One-Group Pretest-Posttest Design. Hasil penelitian terdapat perbedaan hasil belajar siswa setelah menggunakan model pembelajaran Team Assisted Individualization (TAl) dalam kegiatan belajar mengajar yang telah dilaksanakan. Hasil presentase ketuntasan belajar 28,57 \% naik menjadi 89,28\%.

Kata kunci: Model Pembelajaran Team Assisted Individualization (TAI), Hasil Belajar, Tema 9 Kayanya Negriku

Abstract

This research motivated by a lack of student learning interest which results in not achieving KKM values. It because of learning was still teacher-centered and the teacher's lack of creativity in choosing innovative learning models and learning media. This study aimed to determine whether the Team Assisted Individualization (TAI) model is effective against the learning outcomes of the fourth grade Elementary Natural Resources Preservation in Indonesia SD N Sidomulyo 04 Ungaran. This type of research is quantitative research in the form of Pre Experimental Design with One-Group PretestPosttest Design. The results of the study there are differences in student learning outcomes after using the Team Assisted Individualization (TAl) learning model in teaching and learning activities that have been carried out. The results of the percentage of learning completeness $28.57 \%$ rose to $89.28 \%$.
\end{abstract}

Keywords: Model Team Assisted Individualization (TAI) Learning, Learning Outcomes, 9th Theme Is My Country 


\section{Pendahuluan}

Pendidikan merupakan upaya peningkatan kualitas peserta didik setelah melalui usahausaha belajar guna mencapai tujuan tertentu. Tujuan yang diharapkan adalah agar siswa mampu mengembangkan potensi yang ada pada dirinya sehingga dapat berguna bagi diri sendiri maupun orang lain. Hal ini tercantum dalam Undang-undang Repulik Indonesia Nomor 20 tahun 2003 tentang Sistem Pendidikan Nasional Pasal 1 ayat 1 yang menjelaskan bahwa, pendidikan merupakan:

Usaha sadar dan terencana untuk mewujudkan suasana belajar dan proses belajar agar siswa secara aktif mengembangkan potensi dirinya untuk memiliki kekuatan spiritual keagamaan, pengendalian diri, kepribadian, kecerdasan, akhlak mulia, serta keterampilan yang diperlukan dirinya, masyarakat, bangsa dan negara. Hal tersebut dapat diwujudkan dengan sistem pendidikan yang jelas, yakni pendidikan berbasis karakter.

Belajar adalah suatu proses yang dilakukan seseorang agar orang tersebut dapat mengetahui hal yang belum dia ketahui, mengerti apa yang sebelumnya belum dimengerti. Dalam pelaksanaan pembelajaran, suatu pendidikan biasanya diukur dengan hasil belajar siswa yang telah menjalani jenjang pendidikan tertentu. Semakin rendah hasil belajar siswa berarti pendidikan itu belum berhasil untuk mendidik siswa dan dikatakan tingginya hasil belajar berarti proses pendidikan berjalan baik. Hasil belajar yang tinggi atau rendah menunjukkan keberhasilan guru dalam menyampaikan materi pelajaran dalam proses pembelajaran. Sedangkan Hasil belajar adalah kemampuan-kemampuan yang dimiliki siswa setelah menerima pengalaman belajarnya. Kemampuan-kemampuan tersebut mencakup aspek kognitif, afektif dan psikomotor. Hasil belajar dapat dilihat melalui kegiatan evaluasi yang bertujuan untuk mendapatkan data pembuktian yang akan menunjukkan tingkat kemampuan siswa dalam mencapai tujuan pembelajaran. Hasil belajar adalah kemampuan-kemampuan yang dimiliki siswa setelah ia menerima pengalaman belajar.

Berdasarkan hasil observasi dan wawancara yang dilakukan peneliti kepada guru kelas IV yaitu Bapak Doni Agung Nugroho, S.Pd pada tanggal 15 Oktober 2018 di SD N Sidomulyo 04 Ungaran bahwa masalah pembelajaran menggunakan kurikulum 2013 adalah guru masih menggunakan pembelajaran pendekatan mata pelajaran belum menyentuh ke pembelajaran tematik terintegrasi karena guru harus menggabungkan beberapa mata pelajaran menjadi satu (integrasi) namun dalam penilaiannya guru harus memisahkan mata pelajaran yang terintegrasikan menjadi satu mata pelajaran. Sehingga guru cenderung mengelompokkan suatu mata pelajaran untuk mempermudah dalam perhitungan penilaian. Akibatnya, siswa kebingungan dengan pembelajaran tematik dan siswa kurang memiliki rasa tanggungjawab akan tugas yang dibebankan setiap kompetensi dasar (KD) dalam suatu mata pelajaran. Guru yang masih menggunakan pembelajaran konvensional secara monoton dalam kegiatan pembelajaran di kelas, sehingga suasana kelas terlihat kaku dan didominasi guru. Sebagian besar siswa pasif dalam pembelajaran mereka cenderung hanya duduk, mencatat dan mendengarkan apa yang disampaikan guru dan sebagian kecil yang bertanya. Perlu adanya suatu model pembelajaran yang inovatif yang dapat merangsang siswa berpartisipasi aktif dalam pembelajaran sehingga dapat memperoleh hasil belajar yang optimal.

Berdasarkan hasil observasi penelitian yang dilakukan di SD Negeri Sidomulyo 04 Ungaran diketahui bahwa disana guru belum menggunakan model pembelajaran yang bervariasi salah satunya model pembelajaran Team Assisted Individualization (TAl) sehingga menunjukkan bahwa dalam proses belajar mengajar beberapa mengalami kesulitan dalam memahami materi pelajaran yang disampaikan oleh guru. Peneliti melihat bahwa model pembelajaran yang sering digunakan oleh guru di sekolah adalah model pembelajaran yang didominasi dengan metode ceramah (konvensional), pemberian tugas, dan diskusi kelompok. Pembelajaran dimulai dengan penjelasan materi oleh guru, dilanjutkan dengan tanya jawab sekilas tentang pemahaman siswa, dan kemudian diskusi dalam mengerjakan soal-soal. Dalam kegiatan belajar tidak menggunakan model pembelajaran sehingga metode diskusi dan tanya jawab tersebut tidak efektif, siswa cenderung pasif dalam mengikuti pembelajaran sehingga tidak ada umpan balik antar guru dan siswa. 
Salah satu solusi yang dapat diterapkan untuk mengatasi permasalahan pembelajaran tersebut yaitu dengan mengubah model konvesional menjadi model kooperatif. Model pembelajaran kooperatif merupakan model pembelajaran yang dilakukan secara berkelompok dengan tingkat kemampuan yang berbeda. Dalam menyelesaikan tugas kelompoknya, setiap anggota kelompok harus saling bekerja sama dan saling membantu untuk memahami materi pelajaran. Dalam pembelajaran kooperatif, belajar dikatakan belum selesai jika salah satu teman dalam kelompok belum menguasai bahan pelajaran. Jadi, setiap anggota kelompok memiliki tanggung jawab yang sama untuk keberhasilan kelompoknya.

Salah satu model pembelajaran kooperatif yang tepat untuk diterapkan adalah model Team Assisted Individualization. Pada penerapannya model TAI, peserta didik ditempatkan dalam kelompok-kelompok yang heterogen dan selanjutnya diikuti dengan pemberian bantuan secara individu bagi peserta didik yang memerlukannya. Model TAI dikembangkan karena membangun pemikiran yang bersifat konstruktif, meningkatkan minat dan motivasi dalam proses belajar mengajar, sehingga hal ini mampu membuat minat belajar siswa dalam proses pembelajaran meningkat, dan tidak ada lagi anggapan bagi siswa bahwa belajar itu guru yang lebih aktif dan siswa hanya menjadi seorang pendengar saja. Dengan pembelajaran kelompok, diharapkan para peserta didik dapat meningkatkan pemikiran kritisnya, kreatif, tan menambahkan rasa sosial yang tinggi sehingga dapat berpengaruh juga terhadap hasil belajar siswa menjadi tinggi pula.

Model Team Assisted Individualization ini menggabungkan antara model pembelajaran kooperatif dan model pembelajaran individual dimana pembelajaran yang dilakukan yaitu secara berkelompok dengan seorang siswa yang lebih mampu berperan sebagai asisten yang bertugas membantu secara individu siswa lain yang kurang mampu dalam kelompok lain. Model Team Assisted Individualization akan memotivasi siswa untuk saling membantu anggota kelompoknya sehingga tercipta semangat dalam belajar disebabkan karena saat diskusi berlangsung soal-soal saling dibahas oleh anggota kelompok, dan semua anggota kelompok bertangggung jawab atas keseluruhan jawaban sebagai tanggung jawab bersama. Model pembelajaran kooperatif tipe Team Assisted Individualization diharapkan efektif dalam proses pembelajaran pada materi, latihan soal-soal atau pemecahan masalah dan diskusi kelompok. Model ini juga menuntut siswa untuk saling bekerjasama dan bertanggungjawab secara individu terhadap keberhasilannya dan kelompoknya, sehingga model pembelajaran Team Assisted Individualization ini sangat cocok diterapkan pada materi Tema 9 Kayanya Negriku Subtema 3 Pelestarian Kekayaan Sumber Daya Alam di Indonesia karena membutuhkan kemampuan yang baik dari peserta didik dalam mengerjakan soal-soal.

Hasil penelitian Megawati (2012) menemukan bahwa Implementasi Model Pembelajaran Kooperatif Tipe Team Assisted Individualizationdapat meningkatkan Keaktifan Siswa kelas XI IPS 1 SMA Negeri 1 Banjarnegara Tahun Ajaran 2011/2012. Peningkatan ini terlihat dari kenaikan persentase Keaktifan Siswa dalam pembelajaran akuntansi di kelas.

Implementasi Model Pembelajaran Kooperatif Tipe Team Assisted Individualizationdapat meningkatkan Hasil Belajar Akuntansi Siswa kelas XI IPS 1 SMA Negeri 1 Banjarnegara Tahun Ajaran 2011/2012.

Hasil penelitian Ratnaningsih (2016) menyatakan bahwa ada pengaruh penggunaan model pembelajaran kooperatif tipe TAI (Team Assisted Individualization) terhadap hasil belajar mata pelajaran IPS pokok bahasan perjuangan mempersiapkan proklamasi kemerdekaan pada kelas V di SD Negeri Jurugentong"

Halih (2016) juga menyatakan bahwa terdapat pengaruh hasil belajar matematika dengan model pembelajaran TAl (Team Assisted Individualization) terhadap hasil belajar siswa di SMP Rahmat Surabaya tahun pelajaran 2015/2016. Siswa yang diberi model pembelajaran TAI (Team Assisted Individualization) memiliki nilai rata-rata yang lebih tinggi daripada model pembelajaran konvensional.

Ana (2017), Hasil penelitian dari 30 peserta didik yang diberikan perlakuan (treatment) model Teams Assisted Individualization (TAI) terhadap peserta didik yang hasil belajar IPS Terpadu termasuk dalam kategori tuntas sebanyak 21 peserta didik atau sebesar $70 \%$, sedangkan peserta didik yang hasil belajar IPS terpadu termasuk kategori belum tuntas 
sebanyak 9 peserta didik atau sebesar $30 \%$. Kemudian, dari hasil analisis yang dilakukan maka terbukti bahwa ada pengaruh yang positif penggunaan model Teams Assisted Individualization (TAI) terhadap hasil belajar IPS Terpadu peserta didik kelas VIII.

Berdasarkan analisis data maka dapat disimpulkan bahwa "Ada pengaruh yang positif penggunaan model Teams Assisted Individualization (TAI) terhadap hasil belajar IPS Terpadu kelas VIII MTs AI-Muhsin Metro".

\section{Metode}

Peneliti melakukan penelitian di SD Negeri Sidomulyo 04 Ungaran pada kelas IV. penelitian ini dilaksanakan pada Semester II Tahun Ajaran 2018/2019 bulan April - Mei dan pengambilan data dilaksanakan pada tanggal $14-16$ Mei 2019. Dalam penelitian ini terdapat dua variabel, yaitu variabel bebas dan variabel terikat:

1. Variabel Bebas $(\mathrm{X})$

Variabel bebas adalah variabel yang mempengaruhi atau yang menjadi sebab perubahan. Variabel bebas pada penelitian ini yaitu model Team Assisted Individualization yang diterapkan pada pembelajaran subtema pelestarian kekayaan sumber daya alam di Indonesia.

2. Variabel Terikat (Y)

Variabel yang dipengaruhi aatau yang menjadi akibat, karena adanya variabel bebas. Variabel terikat pada penelitian ini adalah hasil belajar subtema pelestarian kekayaan sumber daya alam di Indonesia kelas IV SD Negeri Sidomulyo 04 Ungaran.

Metode penelitian yang digunakan adalah metode penelitian eksperimen. Menurut Sugiyono (2017: 107) metode penelitian eksperimen adalah metode penelitian yang digunakan untuk mencari pengaruh perlakuan tertentu terhadap yang lain dalam kondisi yang terkendalikan.

Pada penelitian ini merupakan kuantitatif. Desain penelitian yang digunakan dalam penelitian ini adalah pre-experimental design dengan bentuk bentuk one-group pretest-posttest design.

Populasi dalam penelitian ini adalah keseluruhan siswa kelas IV SD Negeri Sidomulyo 04 Ungaran. Menurut Sugiyono (2017: 118) sampel adalah bagian dari jumlah dan karakteristik yang dimiliki oleh populasi tersebut.Sampel dalam penelitian ini adalah siswa kelas IV yang berjumlah 28 yang terdiri 14 perempuan dan laki-laki 14 siswa. Teknik sampling yang digunakan dalam penelitian ini adalah Nonprobability Sampling jenis sampling jenuh. "Sampling jenuh adalah teknik penentuan sampel bila semua anggota populasi digunakan sebagai sampel" (Sugiyono, 2017:124). Sampling jenuh pada penelitian ini semua anggota populasi yang berada di kelas IV SD Negeri Sidomulyo 04 digunakan sebagai sampel.

Teknik pengumpulan data menggunakan non tes diantaranya Observasi, wawancara, dan dokumentasi. Dalam peneliti melibatkan diri dalam situasi subjek yang diteliti sebelum dan selama dilaksanakan pembelajaran menggunakan dokumentasi dan tes tertulis. Instrumen penelitian berupa lembar wawancara, dokumentasi berupa foto kegiatan pembelajaran, tes meliputi bentuk tes, metode penysusnan tes, uji instrumen tes (validitas, reliabilitas, taraf kesukaran, daya pembeda).

Teknik analisis data berupa analisis data adapun rumus yang digunakan uji normalitas awal (pretest) dan uji normalitas akhir (pretest). Kemudian menggunakan uji t atau uji hipotesis, uji $n$ gain untuk mengetahui pretest ke posttest, selanjutnya uji ketuntasan belajar berupa uji ketuntasan individual dan uji ketuntasan klasikal. Dengan kriteria siswa telah menguasai sekurang-kurangnya $75 \%$ terhadap materi setiap bahasan yang diajukan. Ketuntasan individu dan klasikal $\geq 75$ tuntas. 


\section{Hasil Dan Pembahasan}

Dari hasil penelitian yang dilakukan oleh peneliti selama melakukan penelitian maka diperoleh data hasil belajar siswa dalam ranah kognitif (pengetahuan) yaitu nilai pretest dan posttest sebagai berikut:

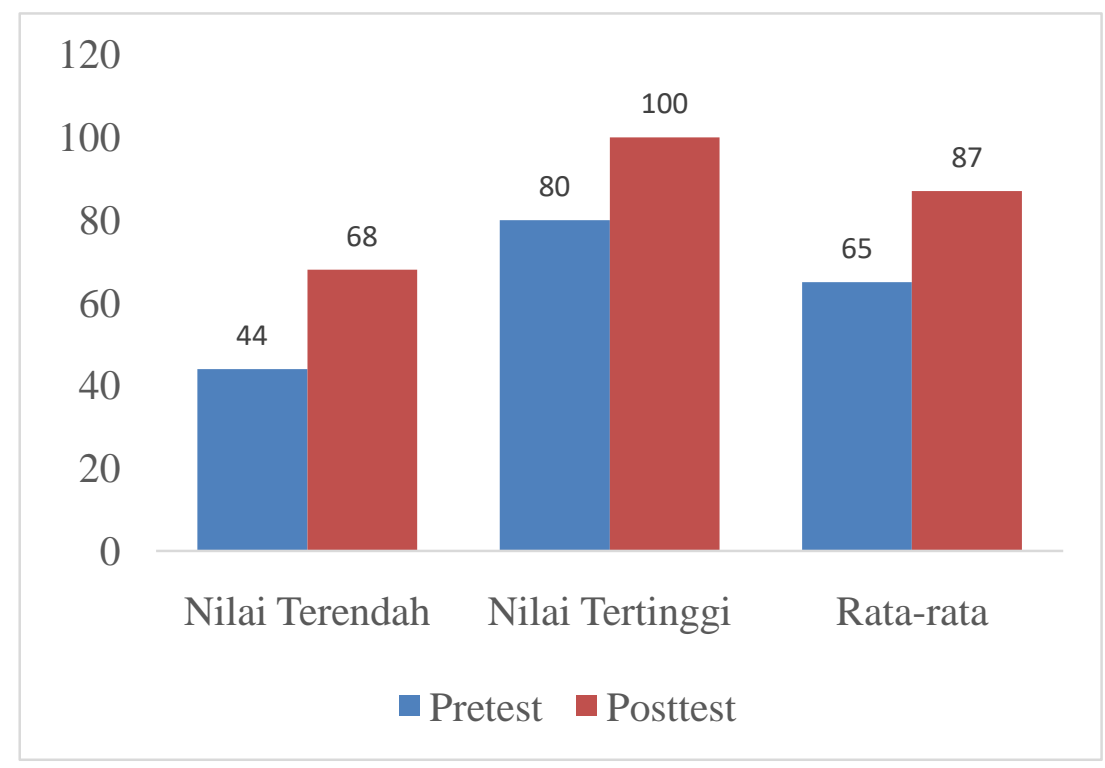

Gambar 1 Nilai Terendah, Tertinggi dan Rata-rata Pretest-Posttest

Berdasarkan Gambar 1 dapat diketahui bahwa nilai rata-rata siswa sebelum diberikan perlakuan sebesar 65 dan nilai rata-rata siswa sesudah diberi perlakuan sebesar 87 Setelah diberi perlakuan model pembelajaran Team Assisted Individualiztion nilai rata-rata hasil belajar siswa mengalami peningkatan sebesar 22.

Uji normalitas awal digunakan untuk mengetahui apakah hasil awal (pretest) berdistribusi normal atau tidak.

Tabel 1. Hasil Uji Normalitas Awal

\begin{tabular}{cc}
\hline Kriteria & Hasil \\
\hline $\mathrm{N}$ & 28 \\
Lo & 0,088 \\
$\mathrm{~L}_{\text {tabel }}$ & 0,167 \\
Kesimpulan & Berdistribusi Normal \\
\hline & Sumber: Data Hasil Penelitian
\end{tabular}

Berdasarkan Tabel 1 hasil uji normalitas awal (pretest) setelah mencari harga $L_{\text {tabel }}$ dari nilai kritis uji liliefors dengan taraf signifikan $\alpha=5 \%$ dan $n=28$ diperoleh $L_{\text {tabel }}=0,088$. Sehingga dapat disimpulkan bahwa $\mathrm{L}_{0}<\mathrm{L}_{\text {tabel }}$ yaitu: 0,088 $<0,167$ maka $\mathrm{H}_{0}$ diterima. Hasil uji normalitas menunjukkan bahwa data pretest siswa berasal dari populasi yang berdistribusi normal.

Uji normalitas akhir digunkan untuk mengetahui apakah hasil akhir (posttest) berdistribusi normal atau tidak.

Tabel 2. Hasil Uji Normalitas Akhir

\begin{tabular}{cc}
\hline Kriteria & Hasil \\
\hline $\mathrm{N}$ & 28 \\
\hline
\end{tabular}




\begin{tabular}{cc}
\hline Lo & 0,124 \\
\hline $\mathrm{L}_{\text {tabel }}$ & 0,167 \\
\hline Kesimpulan & Berdistribusi Normal \\
\hline & Sumber: Data Hasil Penelitian
\end{tabular}

Berdasarkan Tabel 2 hasil uji normalitas awal (posttest) setelah mencari harga $L_{\text {tabel }}$ dari nilai kritis uji liliefors dengan taraf signifikan $\alpha=5 \%$ dan $n=28$ diperoleh $L_{\text {tabel }}=0,167$. Sehingga dapat disimpulkan bahwa $L_{0}<L_{\text {tabel }}$ yaitu: $0,124<0,167$ maka $H_{0}$ diterima. Hasil uji normalitas menunjukkan bahwa data posttest siswa berasal dari populasi yang berdistribusi normal.

Tabel 2. Uji T

\begin{tabular}{cc}
\hline Kriteria & Hasil Uji $-\mathrm{t}$ \\
\hline $\mathrm{N}$ & 28 \\
$\mathrm{t}_{\text {hitung }}$ & 9,324 \\
$\mathrm{t}_{\text {tabel }}$ & 2,052 \\
Taraf Signifikan & $5 \%$ \\
Kesimpulan & $\mathrm{H}_{0}$ Ditolak \\
\hline
\end{tabular}

Berdasarkan Tabel 2 setelah menerapkan model pembelajaran Team Assisted Individualization data nilai pretest dan posttest dianalis uji-t bahwa berdasarkan uji-t terdapat perbedaan yang signifikan terhadap hasil belajar subtema pelestarian kekayaan sumber daya alam di Indonesia siswa kelas IV dalam kegiatan belajar. Hal ini dibuktikan dengan perhitungan uji-t hasing $t_{\text {hitung }}$ sebesar 9,324 dengan distribusi uji-t diperoleh $\mathrm{db}=\mathrm{n}-1=28-1=27$ dengan taraf signifikan $5 \%$ di dapatkan $t_{\text {tabel }}$ sebesar 2,052 sehingga $t_{\text {hitung }}>t_{\text {tabel }}$ atau 9,324 $>2,052$ yang artinya $\mathrm{H}_{0}$ ditolak $\mathrm{H}_{\mathrm{a}}$ diterima. Perhitungan menunjukkan bahwa terdapat perbedaan pada hasil belajar siswa setelah menggunakan model pembelajaran Team Assisted Individualization dalam kegiatan pembelajaran yang telah dilakukan. Sehingga dapat disimpulkan bahwa pembelajaran dengan menggunakan model pembelajaran Team Assisted Individualization efektif terhadap hasil belajar hasil belajar subtema pelestarian kekayaan sumber daya alam di Indonesia siswa kelas IV siswa dalam ranah kognitif (pengetahuan).

Tabel 4. Hasil Perhitungan Uji Gain

\begin{tabular}{clllll}
\hline \multirow{2}{*}{ Responden } & Nilai Rata-rata & \multirow{2}{*}{ Gain } & \multirow{2}{*}{ Gain (\%) } & \multirow{2}{*}{ Kriteria } \\
\cline { 2 - 5 } & Pretest & Posttest & & & \\
\hline 28 & 65 & 87 & 0,62 & $63 \%$ & Sedang \\
\hline & & & & \multicolumn{2}{c}{ Sumber: Data Hasil Penelitian }
\end{tabular}

Berdasarkan Tabel 4 Peningkatan rata-rata uji gain dapat diketahui bahwa ada penngkatan hasil belajar tentang Tema 9 Kayanya Negriku Subtema 3 Pelestarian Kekayaan Sumber Daya Alam Di Indonesia setelah memdapatkan perlakuan di dalam pembelajaran menggunakan model Team Assisted Individualization dengan uji gain sebesar 0,62 nilai presentasi uji gain $63 \%$ maka peningkatan hasil belajar subtema 3 Pelestarian Kekayaan Sumber Daya Alam Di Indonesia pada siswa kelas IV memiiliki kriteria sedang.

Tabel 5. Ketuntasan Belajar Klasikal

\begin{tabular}{ccccc}
\hline \multirow{2}{*}{ No. } & \multirow{2}{*}{ Hasil Belajar } & Tingkat Minimal & \multicolumn{2}{c}{ Presentase Ketuntasan Klasikal } \\
\cline { 4 - 5 } & Ketuntasan & \multicolumn{2}{c}{ Tuntas } & Tidak Tuntas \\
\hline 1. & Pretest & $75 \%$ & $28,57 \%$ & $71,42 \%$ \\
2. & Posttest & $75 \%$ & $(8$ siswa) & $(20$ siswa $)$ \\
\hline
\end{tabular}


Dari perhitungan ketuntasan belajar klasikal pada pretest diperoleh $28,57 \%$ dari jumlah keseluruhan. Sedangkan perhitungan ketuntasan belajar klasikal pada posttest bahwa jumlah siswa 16 siswa yang mengikuti tes dan sebanyak 15 siswa yang mencapai ketuntasan belajar sesuai nilai KKM. Dan sebanyak 1 siswa yang belum dapat mencapai ketuntasan belajar sesuai nilai $\mathrm{KKm}$. Dari perhitungan diatas yang menggunkan rumus ketuntasan belajar klasikal diperoleh 93,75\% dari jumlah keseluruhan.

\section{Simpulan dan Saran}

Berdasarkan penelitian yang telah dilakukan oleh peneliti di kelas IV SD Negeri Sidomulyo 04 Ungaran maka dapat ditarik kesimpulan bahwa model pembelajaran Team Assisted Individualization (TAI) efektif terhadap subtema pelestarian kekayaan sumber daya alam di Indonesia pada siswakelas IV SD Negeri Sidomulyo 04 Ungaran. Simpulan yang peneliti buat ini diperkuat dengan hasil dari uji t yang didapat nilai $t_{\text {hitung }}$ sebesar sebesar 9,324 sedangkan $t_{\text {tabel }}$ sebesar 2,052. Karena $t_{\text {hitung }}>t_{\text {tabel }}$ yaitu sebesar 9,324 $>2,052$ maka $\mathrm{H}_{0}$ ditolak dan $\mathrm{H}_{\mathrm{a}}$ diterima yang artinya rata-rata nilai siswa sebelum menggunakan model pembelajaran Team Assisted Individualization (TAl) lebih besar rata-rata nilai siswa setelah menggunakan model pembelajaran Team Assisted Individualization (TAI). Rata-rata nilai pretest hanya 65 dan nilai posttest menjadi 87 dengan ketuntasan belajar klasikal ketika pretest hanya $10,71 \%$ dan ketika posttest menjadi $89,28 \%$.

Berdasarkan hasil penelitian yang diperoleh, agar proses pembelajaran dapat memberikan hasil yang maksimal, maka saran yang disampaikan antara lain:

Guru dapat menerapkan model Team Assisted Individualization sebagai salah satu alternative model pembelajaran yang memberikan pengaruh yang positif pada siswa sehingga dapat meningkatkan hasil belajar siswa.

Guru dapat menerapkan model Team Assisted Individualization ini sebagai variasi pembelajaran di dalam kelas dan dapat dikolaborasikan dengan media pembelajaran dengan menyesuaikan materi pembelajaran.

\section{Daftar Rujukan}

Ana Hoirunnis. 2017. Penggunaan Model Teams Assisted Individualization (TAI)Terhadap Hasil Belajar Ips Terpadu. JURNAL PROMOSI Jurnal Pendidikan Ekonomi UM Metro Vol.5. No.2 (2017) 124-130

Arikunto, Suharsimi. 2010. Prosedur Penelitian Suatu Pendekatan Praktik. Jakarta: Rineka Cipta.

Daryanto. 2014. Pembelajaran Tematik Terpadu Terintegrasi Kurikulum 2013. Gava Media. Yogyakarta.

Dimyati dan Mudjiono. 2013. Belajar \& Pembelajaran. Jakarta: Rineka Cipta.

Halih Moh. 2016. Pengaruh Model Pembelajaran TAI (Team Assisted Individualization) Terhadap Hasil Belajar Siswa. JURNAL BUANA MATEMATIKA. Vol. 6, No. 2, Tahun 2016

Nur Megawati Nur. 2012. Model Pembelajaran Kooperatif Tipe Team Assisted Individualization (TAI) Dalam Meningkatkan Keaktifan Siswa dan Hasil Belajar Akuntansi Siswa Kelas XI IPS 1 SMA Negeri 1 Banjarnegara Tahun Ajaran 2011/2012. Jurnal Pendidikan Akuntansi Indonesia, Vol. X, Halaman 162 - 180 No. 1, Tahun 2012 
Ratnaningsih Indriani. 2016. Pengaruh Model Team Assisted Individualization Terhadap Hasil Belajar IPS Kelas V SD Negeri Jurugentong, Bantul. Jurnal Kurikulum dan Teknologi Pendidikan Edisi Mei 2016

Rusman. 2012. Model-model Pembelajaran, Bandung: Mulia Mandiri Press.

Shoimin, Aris. 2017. 68 Model Pembelajaran Inovatif dalam Kurikulum 2013. Yogyakarta: ArRuzz Media

Slameto. 2010. Belajar dan Faktor-Faktor yang mempengaruhinya. Jakarta: Rineka Cipta.

Slavin, Robert E. 2016. Cooperative Learning. Bandung: Penerbit Nusa Media.

Sugiyono. 2017. Metode Penelitian Pendidikan (Pendekatan Kuantitatif, Kualitatif dan R\&D). Bandung: Alfabeta.

Susanto, Ahmad. 2013. Teori Belajar dan Pembelajaran di Sekolah Dasar. Jakarta: Prenadamedia Group.

Undang - Undang Republik Indonesia, No.20 Tahun 2003 Tentang sistem Pendidikan Nasional. 